US Army Corps

of Engineers ${ }_{\circledast}$

Engineer Research and

Development Center

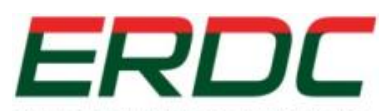

INNOVATIVE SOLUTIONS for a safer, better world

Wetlands Regulatory Assistance Program (WRAP)

\title{
Choosing a Global Positioning System Device for Use in U.S. Army Corps of Engineers Regulatory Districts
}

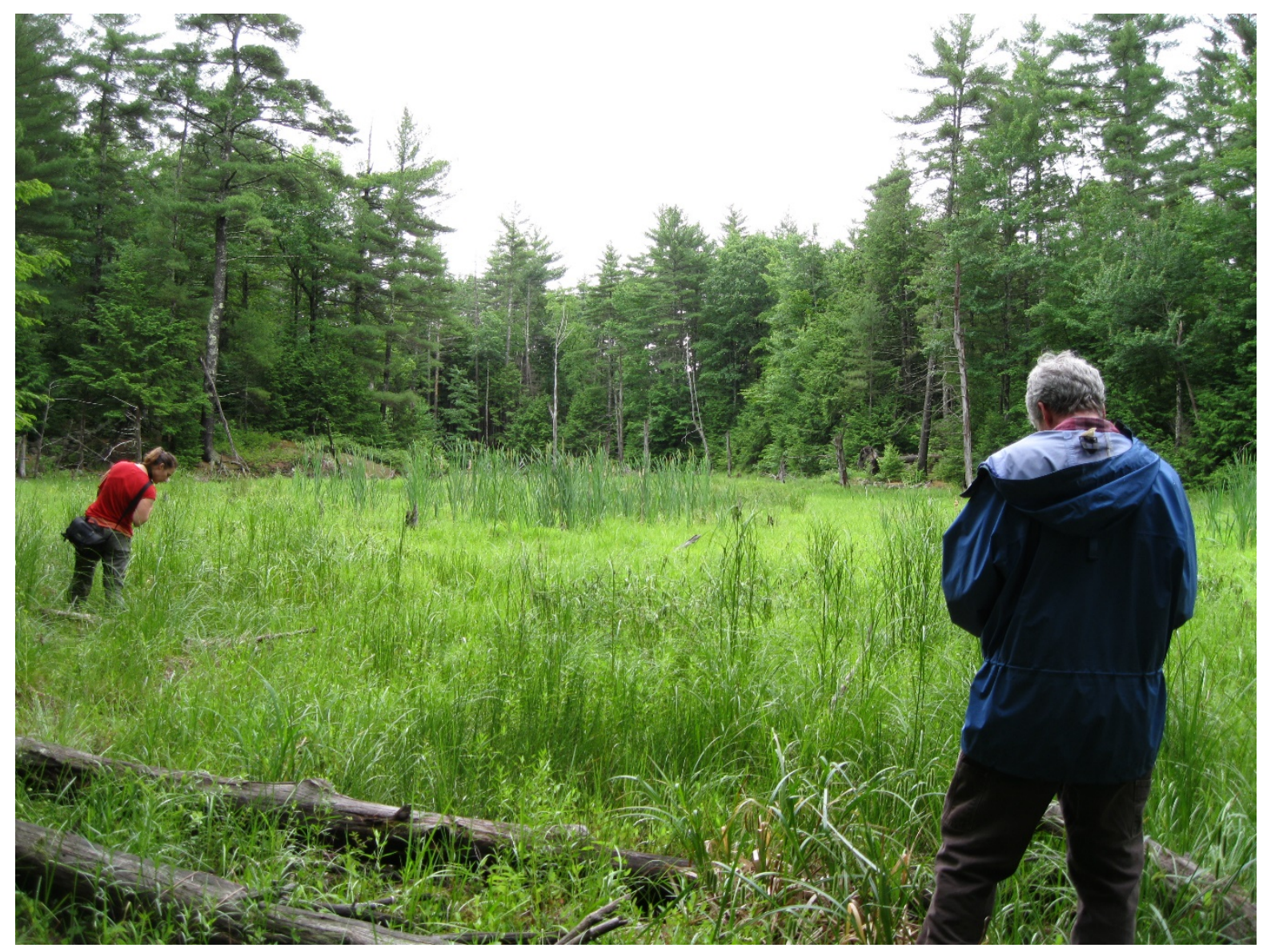


The U.S. Army Engineer Research and Development Center (ERDC) solves the nation's toughest engineering and environmental challenges. ERDC develops innovative solutions in civil and military engineering, geospatial sciences, water resources, and environmental sciences for the Army, the Department of Defense, civilian agencies, and our nation's public good. Find out more at www.erdc.usace.army.mil.

To search for other technical reports published by ERDC, visit the ERDC online library at http://acwc.sdp.sirsi.net/client/default. 


\section{Choosing a Global Positioning System Device for Use in U.S. Army Corps of Engineers Regulatory Districts}

Jennifer J. Goulet

U.S. Army Engineer Research and Development Center (ERDC)

Cold Regions Research and Engineering Laboratory (CRREL)

72 Lyme Road

Hanover, NH 03755-1290

Lindsey E. Lefebvre

U.S. Army Corps of Engineers (USACE)

New England Regulatory District (NAE)

696 Virginia Road

Concord, MA 01742-2718

Y. Jae Chung

U.S. Army Corps of Engineers (USACE)

Institute for Water Resources (IWR)

The Casey Building

7701 Telegraph Road

Alexandria, VA 22315-3822

Final Report

Approved for public release; distribution is unlimited.

Prepared for Headquarters, U.S. Army Corps of Engineers

$441 \mathrm{G}$ Street NW

Washington, DC 20314-1000

Under F9CLBL, “Teaching GIS Class” 


\section{Abstract}

Choosing a Global Positioning System (GPS) device for regulatory purposes involves tradeoffs between price, Corps-approved data transfer mechanisms, and accuracy. This report examines several devices representing different prices and accuracies and discusses accessories, such as external antennas, and software for the field and office. If a U.S. Army Corps of Engineers Regulatory District wants to purchase GPS units, we recommend they be one of the five devices described in this Special Report, depending on district needs, so that we are all using similar devices and can ensure appropriate levels of training and consistency.

GPS technology is constantly being upgraded and refined, ever enhancing our ability to accurately locate positions on the Earth's surface. The devices discussed here will be most useful for regulatory purposes within a few years of the publication date. This report will be updated as these devices become functionally obsolete.

DISCLAIMER: The contents of this report are not to be used for advertising, publication, or promotional purposes. Citation of trade names does not constitute an official endorsement or approval of the use of such commercial products. All product names and trademarks cited are the property of their respective owners. The findings of this report are not to be construed as an official Department of the Army position unless so designated by other authorized documents.

DESTROY THIS REPORT WHEN NO LONGER NEEDED. DO NOT RETURN IT TO THE ORIGINATOR. 


\section{Contents}

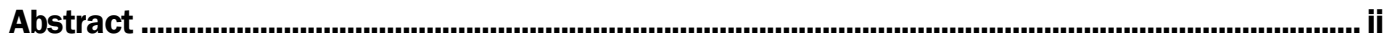

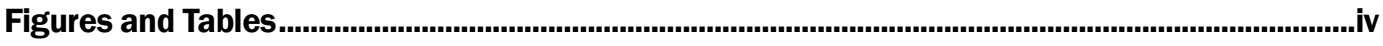

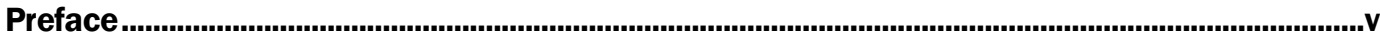

Acronyms and Abbreviations ............................................................................................................vi

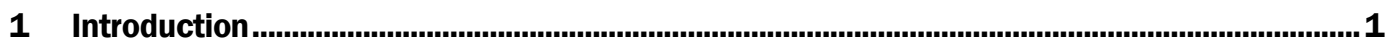

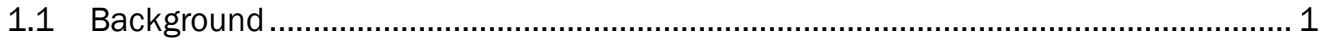

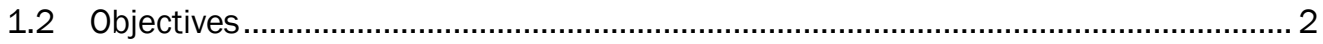

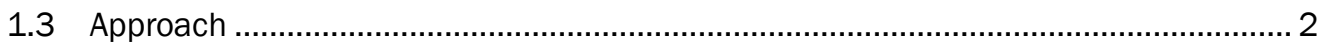

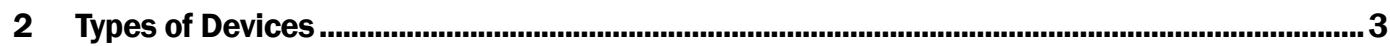

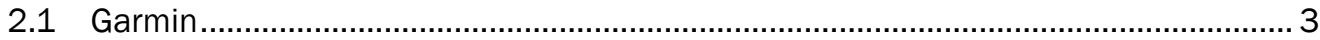

2.2 Magellan eXplorist 710 United States.............................................................. 6

2.3 Trimble Juno 5B Enhanced Wi-Fi and TDC100 Wi-Fi Handhelds ............................ 6

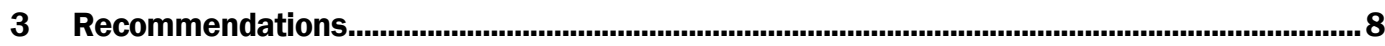

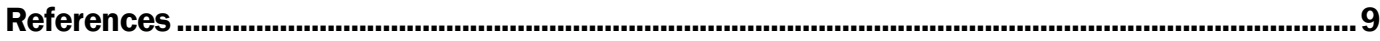

Report Documentation Page 


\section{Figures and Tables}

Tables

1 Summary of select specifications for Global Positioning System devices preferred for USACE Regulatory District tasks $(\mathrm{n} / \mathrm{a}=$ not applicable, $\mu=$ micro, and $\mathrm{HH}=$ handheld, SD $=4 \mathrm{MB}-2 \mathrm{~GB}$ memory card, SDHC [Secure Digital High Capacity] $=4$ GB-32 GB memory card).

2 Comparison of data collection and office software Global Positioning System devices preferred for USACE Regulatory District tasks ( $n / a=$ not applicable) . .5 


\section{Preface}

Support and funding for this project were provided by the U.S. Army Corps of Engineers (USACE) Headquarters through the Wetlands Regulatory Assistance Program (WRAP) under project F9CLBL, "Teaching GIS Class." The authors acknowledge and appreciate the interest and support of Ms. Margaret Gaffney-Smith, Ms. J ennifer Moyer, Ms. Stacey J ensen, and Ms. Karen Mulligan of the USACE Headquarters Regulatory Program and Ms. Sally Stroupe of WRAP.

The work was performed by the LiDAR and Wetlands Group (CEERD$\mathrm{RRC}$ ) of the Remote Sensing and Geographic Information Systems Center of Expertise (RS/ GIS CX) (CEERD-RZR), U.S. Army Engineer Research and Development Center, Cold Regions Research and Engineering Laboratory (ERDC-CRREL); the Institute for Water Resources (IWR); and the New England Regulatory District (NAE). At the time of publication, Dr. Elias Deeb was Chief, CEERD-RRC, and Mr. David Finnegan was Director, CEERD-RZR. The Deputy Director of ERDC-CRREL was Dr. Lance Hansen, and the Director was Dr. J oseph L. Corriveau.

The authors thank Mr. Timothy Baldwin, ERDC-CRREL; Mr. Robert Stout, Detroit District; Mr. J ames Robb, Sacramento Regulatory District; Mr. Elliott Carman, Southwestern Regulatory Division; and Ms. Stacey J ensen, Corps Headquarters, for their thoughtful and insightful reviews.

COL Bryan S. Green was the Commander of ERDC, and Dr. David W. Pittman was the Director. 


\section{Acronyms and Abbreviations}

$\begin{array}{ll}\text { CRREL } & \text { Cold Regions Research and Engineering Laboratory } \\ \text { CX } & \text { Center of Expertise } \\ \text { ERDC } & \text { U.S. Army Engineer Research and Development Center } \\ \text { GIS } & \text { Geographic Information Systems } \\ \text { GPS } & \text { Global Positioning System } \\ \text { HH } & \text { Handheld } \\ \text { IWR } & \text { U.S. Army Engineer Institute for Water Resources } \\ \text { n/a } & \text { Not Applicable } \\ \text { NAE } & \text { U.S. Army New England Regulatory District } \\ \text { RS/GIS } & \text { Remote Sensing/ Geographic Information Systems } \\ \text { SD } & \text { Secure Digital } \\ \text { SDHC } & \text { Secure Digital High Capacity } \\ \text { USACE } & \text { U.S. Army Corps of Engineers } \\ \text { WRAP } & \text { Wetlands Regulatory Assistance Program }\end{array}$




\section{Introduction}

\subsection{Background}

Project Managers for the U.S. Army Corps of Engineers (USACE) Regulatory Districts use Global Positioning System (GPS) devices to collect geospatial data in support of the USACE mission to regulate dredging and filling of wetlands and Waters of the United States under Section 404 of the Clean Water Act (U.S. Congress 1977) and structures or work in navigable waters of the United States under Section 10 of the Rivers and Harbors Act (U.S. Congress 1899). In 2017, Regulatory Headquarters requested information summarizing the advantages and limitations of commonly used GPS devices to determine which devices are most suitable for regulatory purposes. This report is the result of that request. The information it contains will help standardize the geospatial data collected for Regulatory purposes, help ensure appropriate levels of training, and guide District purchases.

Choosing a GPS device for regulatory purposes involves tradeoffs between price, Corps-approved data transfer mechanisms (USACE 2016), and accuracy. Price is always an important consideration when making a purchase. The prices of the devices and supporting software discussed in this report reflect 2017 values. Efficient and secure data transfer mechanisms are also critical when choosing a GPS because USACE cyber security protocol prohibits GPS devices that accept flash media (e.g., SD [Secure Digital] cards) from being connected to CorpsNet computers (USACE 2016). The accuracy of the data collected is also extremely important. The real-time accuracies reported here are variable. Highest accuracies are achieved when a device is stationary, for example mounted on a tripod. Users will experience higher or lower accuracies, depending on atmospheric conditions (e.g., charged particles in the ionosphere and water vapor in the troposphere), obstructions (e.g., buildings and canopy cover), the number and position of satellites in the sky, and the user's latitude (which affects the angle of inclination between the user and the position of geostationary satellites broadcasting correction information). Some of these devices can be paired with an external antenna to improve accuracy. When the external antenna is elevated above obstructions, such as dense canopy, these devices receive a stronger GPS signal and produce more accurate results than devices that lack external antennas. However, none of these devices collect 
survey-grade data out of the box; and factors that limit accuracy should always be taken into consideration.

\subsection{Objectives}

Our objective was to compare and contrast the prices, data transfer mechanisms, and accuracies of GPS devices in the context of tasks performed by USACE Regulatory Project Managers, such as field navigation, verification of wetland delineations, or jurisdictional determinations.

\subsection{Approach}

In 2016, the Institute for Water Resources surveyed the USACE Regulatory Districts regarding GPS devices commonly used for regulatory purposes. Results showed that a wide variety of devices from three major manufacturers, Garmin, Magellan, and Trimble, were used nationally. The Cold Regions Research and Engineering Laboratory researched the specifications of the most technologically advanced and user-friendly models produced by each manufacturer. The information contained in this report was collected from manufacturer websites and specification sheets, interactions with customer support, current users, and sales representatives. 


\section{Types of Devices}

\subsection{Garmin}

Garmin devices, designed for fitness and recreational users, are easy to use and are the least expensive of the three major GPS manufacturers described in Table 1. Freeware accessible through ACE-IT's ServiceTrak website (entered through the App Portal) is available for projecting, converting, and viewing Garmin files and for obtaining digital imagery; so it is not necessary to purchase special software (Table 2). High-end models, such as the Montana 680t or the Oregon 750t, are preloaded with 1:100K topographic maps and support proprietary Birdseye Satellite Imagery. These devices use Bluetooth and the Garmin Connect mobile app to transfer data wirelessly to other GPS units or smartphones within a $10 \mathrm{~m}$ radius (Garmin 2011, 2016). In addition, the app also transfers tracks data from the GPS to the user's account on the Garmin Connect website when connected via Bluetooth and a smartphone to a wireless network (Garmin Technical Support 2017), enabling Project Managers to comply with Corps data transfer protocol (USACE 2016).

However, Garmin devices also have several drawbacks. The first is that Garmin GPS only transmits tracks data to the internet wirelessly (Garmin Technical Support 2017). Therefore, to comply with USACE cyber security protocol, Project Managers must transfer point and polygon data to the USACE network via a stand-alone airgap computer dedicated to scanning data for malware and viruses before transfer to network computers. Second, real-time accuracy is lower than that of other brands. Garmin Technical Support guarantees an accuracy of $15 \mathrm{~m}$ although the average user experiences higher accuracy of 5- 10 m (Garmin Technical Support 2017). Practical uses of the Garmin include coarse-grained navigation, such as navigating to a delineated boundary for field verification, and for points where precision is not critical (e.g., "photo point \#1 within wetland \#4 looking south"). However, this level of accuracy is less useful for other aspects of fieldwork, such as navigating to a precise point along a delineated wetland boundary, mapping polygons, or recording specific points such as "edge of new fill." The Montana series can be used with an external antenna, which could improve accuracy in some situations. But in general, these devices are best used when a high level of accuracy, such as for a delineation or jurisdictional determination, is not required (Table 1). 
Table 1. Summary of select specifications for Global Positioning System devices preferred for USACE Regulatory District tasks $(\mathrm{n} / \mathrm{a}=$ not applicable, $\mu=$ micro, and $\mathrm{HH}=$ handheld, $\mathrm{SD}=4 \mathrm{MB}-2 \mathrm{~GB}$ memory card, SDHC [Secure Digital High Capacity] = 4 GB-32 GB memory card).

\begin{tabular}{|c|c|c|c|c|c|}
\hline \multirow[b]{2}{*}{ Specifications } & \multicolumn{2}{|c|}{ Garmin } & \multirow{2}{*}{$\begin{array}{c}\text { Magellan } \\
\text { eXplorist } 710 \\
\text { United States }\end{array}$} & \multicolumn{2}{|c|}{ Trimble } \\
\hline & Montana 680t & Oregon $750 t$ & & $\begin{array}{c}\text { TDC100 } \\
\text { Wi-Fi Handheld }\end{array}$ & $\begin{array}{c}\text { Juno 5B } \\
\text { Enhanced Wi-Fi } \\
\text { Handheld }\end{array}$ \\
\hline \multicolumn{6}{|c|}{ Global Positioning System } \\
\hline $\begin{array}{l}\text { Average real-time } \\
\text { accuracy }(m)\end{array}$ & $5-10$ & $5-10$ & $3-5$ & $1-2$ & $1-2$ \\
\hline $\begin{array}{l}\text { Compatible with } \\
\text { external antenna }\end{array}$ & Yes & No & No & Yes & Yes \\
\hline Data transfer via Wi-Fi & No & No & No & Yes, all data & Yes, all data \\
\hline Data transfer via Bluetooth & $\begin{array}{l}\text { Tracks only } \\
\text { (.gpx files) }\end{array}$ & $\begin{array}{l}\text { Tracks only } \\
\text { (.gpx files) }\end{array}$ & No & Yes, all data & Yes, all data \\
\hline Camera (MP) & 8 & 8 & 3.2 & 8 & 8 \\
\hline Background maps & $\begin{array}{l}\text { Birdseye Imagery } \\
1: 100 \mathrm{~K} \text { topos }\end{array}$ & $\begin{array}{l}\text { Birdseye Imagery } \\
1: 100 \mathrm{~K} \text { topos }\end{array}$ & $\begin{array}{c}\text { Digital Globe } \\
\text { Imagery, Summit } \\
\text { Series 1:24 K topos, } \\
\text { World Edition, City } \\
\text { Series USA }\end{array}$ & $\begin{array}{c}\text { Google/Open Street } \\
\text { Maps }\end{array}$ & $\begin{array}{c}\text { Google/Open Street } \\
\text { Maps }\end{array}$ \\
\hline \multicolumn{6}{|c|}{ Device } \\
\hline Operating system & $\mathrm{n} / \mathrm{a}$ & $\mathrm{n} / \mathrm{a}$ & $\mathrm{n} / \mathrm{a}$ & $\begin{array}{l}\text { Android } 5.1 \\
\text { "Lollipop" }\end{array}$ & $\begin{array}{c}\text { Windows Embedded } \\
\text { HH } 6.5\end{array}$ \\
\hline Processor & $\mathrm{n} / \mathrm{a}$ & $\mathrm{n} / \mathrm{a}$ & $\mathrm{n} / \mathrm{a}$ & $1.2 \mathrm{GHz}$ & $1.0 \mathrm{GHz}$ \\
\hline Memory (RAM) & $\mathrm{n} / \mathrm{a}$ & $\mathrm{n} / \mathrm{a}$ & $\mathrm{n} / \mathrm{a}$ & $2 \mathrm{~GB}$ & $512 \mathrm{MB}$ \\
\hline Data storage & $8 \mathrm{~GB}$ & $4 \mathrm{~GB}$ & $3 \mathrm{~GB}$ & $8 \mathrm{~GB}$ & $32 \mathrm{~GB}$ \\
\hline Expansion slots & $1 \mu \mathrm{SD}$ & $1 \mu S D$ & $1 \mu S D$ & $1 \mu \mathrm{SD} / \mathrm{SDHC}$ & $1 \mu \mathrm{SD} / \mathrm{SDHC}$ \\
\hline $\begin{array}{l}\text { Screen details } \\
\text { (cm; pixels) }\end{array}$ & $\begin{array}{c}10.2 \\
272 \times 480\end{array}$ & $\begin{array}{c}7.6 \\
200 \times 400\end{array}$ & $\begin{array}{c}7.6 \\
200 \times 400\end{array}$ & $\begin{array}{c}13.5 \\
1280 \times 720\end{array}$ & $\begin{array}{c}10.9 \\
480 \times 800\end{array}$ \\
\hline Display type & $\begin{array}{l}\text { Color, transflective } \\
\text { sunlight readable } \\
\text { dual-orientation } \\
\text { touchscreen }\end{array}$ & $\begin{array}{l}\text { Color, transflective } \\
\text { touch screen }\end{array}$ & $\begin{array}{l}\text { Color, transflective } \\
\text { touch screen }\end{array}$ & $\begin{array}{l}\text { Color, Gorilla Glass, } \\
\text { sunlight readable, } \\
\text { touch screen }\end{array}$ & $\begin{array}{l}\text { Color, Gorilla Glass, } \\
\text { sunlight readable, } \\
\text { touch screen }\end{array}$ \\
\hline Weight (g) & $289-332$ & 210 & 195 & 310 & 450 \\
\hline Battery life (hr) & 16 & 16 & 16 & 10 & 8 \\
\hline \multicolumn{6}{|c|}{ Ruggedness } \\
\hline $\begin{array}{l}\text { Ruggedness: } \\
\text { withstands drop (m) }\end{array}$ & not rated & not rated & not rated & 1.2 & 1.2 \\
\hline Impervious to dust? & not rated & not rated & not rated & Yes, completely & Yes, completely \\
\hline Immersion in water? & up to $1 \mathrm{~m}$ & up to $1 \mathrm{~m}$ & up to $1 \mathrm{~m}$ & up to $1 \mathrm{~m}$ & beyond $1 \mathrm{~m}$ \\
\hline Operating temperature $\left({ }^{\circ} \mathrm{C}\right)$ & not rated & not rated & -10 to 60 & -20 to 60 & -30 to 60 \\
\hline \multicolumn{6}{|c|}{ Price } \\
\hline GSA Advantage (FY17) & $\$ 483-\$ 673$ & $\$ 450-\$ 485$ & $\$ 655$ & Not available* & $\$ 1,889$ \\
\hline
\end{tabular}

*Retails for $\$ 999$ at the Trimble store (https://store.trimble.com/) 
Table 2. Comparison of data collection and office software Global Positioning System devices preferred for USACE Regulatory District tasks ( $\mathrm{n} / \mathrm{a}=$ not applicable).

\begin{tabular}{|c|c|c|c|c|}
\hline Device & External Antenna & Data Collection Software & Office Software & $\begin{array}{c}\text { Post- } \\
\text { Processed } \\
\text { Accuracy }(\mathrm{m})\end{array}$ \\
\hline $\begin{array}{l}\text { Garmin } \\
\text { Oregon } 750 t\end{array}$ & $\mathrm{n} / \mathrm{a}$ & \multirow[t]{2}{*}{$\mathrm{n} / \mathrm{a}$} & \multirow[b]{2}{*}{$\begin{array}{l}\text { Birdseye Imagery: Displays high, } \\
\text { medium, and low resolution } \\
\text { imagery (subscription fee of } \\
\text { \$30/year) } \\
\text { DRNGPS Freeware: Downloads } \\
\text { data from GPS to air gap computer, } \\
\text { converts file formats, } \\
\text { projects/transforms to NAD83 } \\
\text { Basecamp Freeware: Displays and } \\
\text { downloads imagery, transfers data } \\
\text { and images between GPS and the } \\
\text { internet, has limited cloud } \\
\text { capability via Garmin Connect App }\end{array}$} & \multirow[t]{2}{*}{$\mathrm{n} / \mathrm{a}$} \\
\hline $\begin{array}{l}\text { Garmin } \\
\text { Montana } \\
680 t\end{array}$ & $\begin{array}{l}\text { GA 25MCX } \\
\text { Remote GPS } \\
\text { Antenna } \\
\text { (\$31.49) }\end{array}$ & & & \\
\hline $\begin{array}{l}\text { Magellan } \\
\text { explorist } \\
710\end{array}$ & $\mathrm{n} / \mathrm{a}$ & $\mathrm{n} / \mathrm{a}$ & $\begin{array}{l}\text { VantagePoint Freeware: Displays } \\
\text { and transfers tracks, waypoints, } \\
\text { imagery, topo maps, and multi- } \\
\text { media files between the GPS, PC } \\
\text { and the internet }\end{array}$ & $1-3$ \\
\hline \multirow[t]{2}{*}{$\begin{array}{l}\text { Trimble } \\
\text { TDC100 } \\
\text { Wi-Fi } \\
\text { Handheld }\end{array}$} & \multirow[t]{2}{*}{$\begin{array}{l}\text { External } \\
\text { Antenna GPS } \\
\& \text { GLONASS } \\
\text { compatible } \\
(\$ 39)\end{array}$} & $\begin{array}{l}\text { Esri Collector for ArcGIS: } \\
\text { Collects feature and attribute } \\
\text { data, enables navigation, } \\
\text { syncs data to Esri's cloud, } \\
\text { transforms and projects data } \\
\text { (no license fee) }\end{array}$ & $\begin{array}{l}\text { ArcGIS online: Creates and shares } \\
\text { maps, views/manages data, } \\
\text { converts files, transforms and } \\
\text { projects data }\end{array}$ & \multirow[t]{2}{*}{$\mathrm{n} / \mathrm{a}$} \\
\hline & & $\begin{array}{l}\text { Terraflex Basic: Collects new } \\
\text { feature data ( } \$ 250 / \text { year) } \\
\text { Terraflex Advanced: Imports } \\
\text { existing data, enables } \\
\text { navigation in field, collects } \\
\text { feature and attribute data, } \\
\text { edits and maintains data } \\
(\$ 400 / \text { year) }\end{array}$ & $\begin{array}{l}\text { Terraflex Cloud Services: Displays } \\
\text { and manages data } \\
\text { Esri ArcMap plugin: Converts files } \\
\text { to .shp or .kml } \\
\text { DRNGPS: Used with ArcMap, } \\
\text { projects or transforms to NAD83 }\end{array}$ & \\
\hline \multirow[t]{2}{*}{$\begin{array}{l}\text { Trimble } \\
\text { Juno 5B } \\
\text { Enhanced } \\
\text { Wi-Fi } \\
\text { Handheld }\end{array}$} & \multirow[t]{2}{*}{$\begin{array}{l}\text { External } \\
\text { Antenna GPS } \\
\text { \& GLONASS } \\
\text { compatible } \\
(\$ 35)\end{array}$} & $\begin{array}{l}\text { ArcPad: Creates, edits, and } \\
\text { analyzes GIS data, including } \\
\text { vector and raster files; } \\
\text { browses ArcGIS Online to } \\
\text { select templates and projects }\end{array}$ & $\begin{array}{l}\text { ArcGIS Online: Stores templates for } \\
\text { ArcPad projects; visualizes, edits } \\
\text { and analyzes data }\end{array}$ & \multirow[t]{2}{*}{$\begin{array}{l}\text { Less than } \\
1-2\end{array}$} \\
\hline & & $\begin{array}{l}\text { Terraflex Basic: Only collects } \\
\text { feature (\$250/year) } \\
\text { Terraflex Advanced: Enables } \\
\text { navigation in field, collects } \\
\text { feature and attribute data, } \\
\text { maintains data ( } \$ 400 / \text { year) }\end{array}$ & $\begin{array}{l}\text { Terraflex Cloud Services: Displays } \\
\text { and manages data } \\
\text { Esri ArcMap plugin: Converts files } \\
\text { to .shp or .kml } \\
\text { DRNGPS: Used with ArcMap, } \\
\text { projects or transforms to NAD83 }\end{array}$ & \\
\hline
\end{tabular}




\subsection{Magellan eXplorist 710 United States}

The eXplorist 710, manufactured by Magellan, was designed for recreational users and vehicle navigation. It is rugged and easy to use (Table 1). World Edition and City Series USA vehicle navigation maps with turn-byturn routing and Summit Series USA topographic maps are preloaded. It also supports satellite and aerial imagery from Digital Globe. Use of Digital Globe by the USACE is covered by the FedGov License agreement. A CAC login is available at https:// evwhs.digitalglobe.com/myDigitalGlobe/login. VantagePoint freeware transfers data, maps, and imagery between the eXplorist 710, a PC, and the internet. This software is not approved for use on the USACE network at this time, so installation would require a special request to ACE-IT. Unlike Garmin and Trimble, Magellan does not currently have a workspace in the cloud to which users can upload data. So, data transfer from this GPS to the USACE network is best accomplished via an airgap computer. The eXplorist 710 is fairly inexpensive, and real-time accuracy averages 3- $5 \mathrm{~m}$ (Magellan 2017). Accuracy cannot be increased as this device is not compatible with any of Magellan's external antennas.

The practical uses of the eXplorist 710 are similar to those of a Garmin although somewhat higher accuracy may make it easier to navigate to a particular mapped polygon for field verification of a delineation. This device is also useful for most photo locations because it records videos and voice notes. It may be best used when medium levels of accuracy are required for delineations and jurisdictional determinations.

\subsection{Trimble Juno 5B Enhanced Wi-Fi and TDC100 Wi-Fi Handhelds}

The J uno 5B Enhanced Wi-Fi handheld (J uno) and the TDC100 Wi-Fi handheld (TDC100) are Trimble devices that are designed for GPS/ GIS professionals, who typically require higher levels of accuracy than recreational users. These are also the most rugged of the five devices described here. Both devices transfer data automatically via $\mathrm{Wi}$-Fi, uploading points, lines, polygons, and photos to the user's account in the Trimble cloud where they can be viewed with Google or Open Street map backgrounds. External antennas are available for both devices, enabling them to receive a stronger GPS signal and to produce more accurate results than a device without an external antenna. Under ideal conditions, the J uno collects data with an average accuracy of 1- $2 \mathrm{~m}$ in real-time (Trimble 2010). The less expensive TDC100 collects data with an accuracy of 1- $2 \mathrm{~m}$ less than $1.5 \mathrm{~m}$ is considered typical (Trimble 2016). 
Data collection software is required for both devices. The J uno is compatible with Trimble's Terraflex and more challenging programs such as TerraSync Professional Edition or Esri's ArcPad. Data collected using Terraflex cannot be post-processed to increase accuracy. Similarly, data collected using ArcPad can be post-processed only if a supported external receiver is connected. However, data collected with TerraSync can be postprocessed with Pathfinder Office to increase accuracy. The TDC100 is compatible with the Esri Collector app and Terraflex. Practical uses of these devices include recording points during a delineation or on the edge of new fill. These devices could also map the extent of a wetland polygon or the extent of new fill. Therefore, these devices are best used when high levels of accuracy are needed for delineations, jurisdictional determinations, and enforcement actions.

Using templates from either Terraflex or Esri Collector for ArcGIS, Corps Districts could create customized forms for data collection with required and optional fields. Both apps can be used to navigate in the field, collect feature and attribute data, and view or manage data in the cloud. They differ in regard to data format and transformations. Terraflex currently supports only one coordinate system, WGS84, so a free ArcMap plugin is needed to convert data from Trimble's proprietary format (.ssf) to a feature class and transform to NAD83, the format required for Federal data storage. In contrast, Esri Collector for ArcGIS enables the user to specify a geographic transformation method in advance, which is applied on the fly as data are collected. Of course, the correct method must be chosen for the transformation to be effective. Use of Esri Collector for ArcGIS is covered by the Corps Enterprise License Agreement. It was recently white listed for use on CorpsNet (Blyler 2017). There is currently no Enterprise License for Terraflex, so a license must be purchased each year (Table 2). However, if there is enough interest, perhaps a Corps-wide license, as available for the Esri, could be set up in the future. 


\section{Recommendations}

GPS devices are essential tools used to support the USACE Regulatory mission. If a District Regulatory office wants to purchase GPS units, we recommend it being one of these five, depending on district needs, so that we are all using similar devices and can ensure appropriate levels of training and consistency. These devices will be most useful for regulatory purposes within a few years of the publication date of this report because GPS technology is constantly being upgraded and refined. New technologies will make possible the collection of even higher-resolution data in the field. This report will be updated as these devices become functionally obsolete. 


\section{References}

Blyler, N. 2017. Personal communication with J ennifer Goulet via email. 5 September. Washington, DC: U.S. Army Corps of Engineers Civil Works, Geospatial Community of Practice.

Garmin. 2011. Garmin Montana 600 Series Owner's Manual. Garmin Ltd. https://support.garmin.com/support/manuals/manuals.htm?partNo=010-0153412\&language $=e n \&$ country $=G B$ (accessed 3 August 2016).

_ 2016. Garmin Oregon 700 Series Owner's Manual. Garmin Ltd. https://support.garmin.com/support/manuals/manuals.htm?partNo=010-01672-01 (accessed 3 August 2016).

Garmin Technical Support. 2017. Personal communication with J ennifer Goulet via telephone. J uly 13. Garmin Ltd.

Magellan. 2017. Magellan eXplorist 710: Specifications. MagellanGPS.com. MiTAC International Corporation. http://www.magellangps.com/Store/eXploristSeries/eXplorist710 (accessed 5 December 2017).

Trimble. 2010. Trimble Juno 5 Series Datasheet. Trimble. https://geospatial.trimble.com/sites/default/files/201710/Juno\%205\%20Series\%20Datasheet_0.pdf (accessed 7J une 2017).

— 2014. Trimble TerraFlex Software Datasheet. Trimble. http://trl.trimble.com/docushare/dsweb/Get/Document-736663/022516125_TerraFlex_TS_1214.pdf (accessed $9 \mathrm{~J}$ une 2017).

— 2016. Trimble TDC100 Series Datasheet. Trimble. https://drive.google.com/file/d/0BxW3dqQ5gdnTWk1yempaNIYt0EU/view (accessed $9 \mathrm{~J}$ une 2017).

U.S. Congress. 1899. Rivers and Harbors Act. 33 U.S.C. §§ 401- 418 et seq., 55th Congress. https://www.gpo.gov/fdsys/pkg/USCODE-2011-title33/pdf/USCODE-2011-title33chap9-subchapl.pdf (accessed 4 December 2017).

1977. Federal Water Pollution Control Act. 33 U.S.C. §§ 1251- 1387 et seq. (amended 27 December 1977), 95th Congress. http://www.gpo.gov/fdsys/pkg/STATUTE91/pdf/STATUTE-91-Pg1566.pdf (accessed 1 December 2017).

USACE (U.S. Army Corps of Engineers). 2016. The Transfer of Data Collected by Global Positioning System (GPS) and Geographic Information System (GIS) Receiver Devices onto CorpsNet. Engineering and Construction Bulletin No. 2016-24. Washington, DC: U.S. Army Corps of Engineers. 


\section{REPORT DOCUMENTATION PAGE}

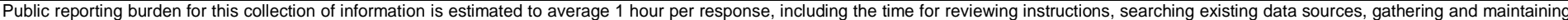

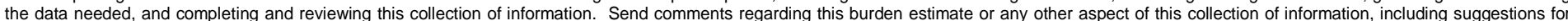

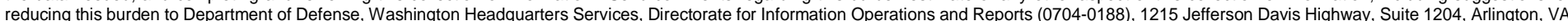

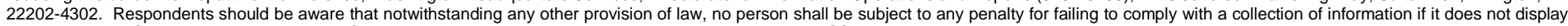
a currently valid OMB control number. PLEASE DO NOT RETURN YOUR FORM TO THE ABOVE ADDRESS.
1. REPORT DATE (DD-MM-YYYY)
2. REPORT TYPE
December 2017
Special Report/Final

\section{TITLE AND SUBTITLE}

Choosing a Global Positioning System Device for Use in U.S. Army Corps of

Engineers Regulatory Districts

DATES COVERED (From - To)

5a. CONTRACT NUMBER

5b. GRANT NUMBER

5c. PROGRAM ELEMENT NUMBER

\section{AUTHOR(S)}

Jennifer J. Goulet, Lindsey E. Lefebvre, and Y. Jae Chung

5d. PROJECT NUMBER

F9CLBL

5e. TASK NUMBER

5f. WORK UNIT NUMBER

8. PERFORMING ORGANIZATION REPORT NUMBER

ERDC/CRREL SR-17-5

U.S. Army Engineer Research and Development Center (ERDC)

Cold Regions Research and Engineering Laboratory (CRREL)

72 Lyme Road

Hanover, NH 03755-1290

9. SPONSORING I MONITORING AGENCY NAME(S) AND ADDRESS(ES)

Headquarters, U.S. Army Corps of Engineers

441 G Street NW

Washington, DC 20314-1000

\section{DISTRIBUTION / AVAILABILITY STATEMENT}

Approved for public release; distribution is unlimited.

\section{SUPPLEMENTARY NOTES}

Wetlands Regulatory Assistance Program (WRAP)

\section{ABSTRACT}

Choosing a Global Positioning System (GPS) device for regulatory purposes involves tradeoffs between price, Corps-approved data transfer mechanisms, and accuracy. This report examines several devices representing different prices and accuracies and discusses accessories, such as external antennas, and software for the field and office. If a U.S. Army Corps of Engineers Regulatory District wants to purchase GPS units, we recommend they be one of the five devices described in this Special Re-port, depending on district needs, so that we are all using similar devices and can ensure appropriate levels of training and consistency.

GPS technology is constantly being upgraded and refined, ever enhancing our ability to accurately locate positions on the Earth's surface. The devices discussed here will be most useful for regulatory purposes within a few years of the publication date. This report will be updated as these devices become functionally obsolete.

\section{SUBJECT TERMS}

Delineation, Geospatial data, Global Positioning System, GPS receivers, OWHM, Regulatory Districts, Wetland management, Wetlands

\section{SECURITY CLASSIFICATION OF:}

\section{a. REPORT}

Unclassified

\section{b. ABSTRACT}

Unclassified

\section{c. THIS PAGE}

Unclassified

\begin{tabular}{c|c|} 
17. LIMITATION & $\begin{array}{c}\text { 18. NUMBER } \\
\text { OF ABSTRACT }\end{array}$ \\
OF PAGES \\
SAR & 18
\end{tabular}

19a. NAME OF RESPONSIBLE PERSON

19b. TELEPHONE NUMBER (include area code) 